\title{
The Quality of Financial Reporting: Sharia Supervisory Board Role in Zakat Management Organization
}

\author{
E. Mediawati \\ Accounting Department, Universitas Pendidikan Indonesia \\ Bandung, INDONESIA \\ elis.mediawati@upi.edu
}

\begin{abstract}
Public trust is closely related to the quality of the financial information which is presented by Zakat Management Organization (ZMO). The information will be useful if the information is able to support the community decision-making to entrust their zakat to ZMO. Sharia Supervisory Board (SSB) is a very important organ in the Islamic financial institutions (IFIs), SSB ensures all the objectives of Islamic governance are achieved, which includes directing, reviewing and supervising all the activities of IFIs in order to adhere to sharia. This study aims to determine the relation role of sharia supervisory board on the quality of financial reporting. The method which is used in this study is a survey method. The unit of analysis in this study is the ZMO in Indonesia. The respondents in this study are director, member of the supervisory board of sharia as well as Zakat collection and utilization. The hypothesis testing uses moment product moment correlation and coefficient of determination (R2).

The result of this research is the relation of sharia supervisory board role with the quality of financial reporting is positive and very strong
\end{abstract}

Keywords: Sharia Supervisory Board, Quality of Financial Reporting, Zakat Management Organization

\section{BACKGROUND}

Zakat is the third pillar of Islam, it must be fulfilled by a muzakki (the person who is obliged to issue zakat), because the rights of others are in the assets which are owned. Zakat in Islam is the worship contains two dimensions they are hablumminallah or vertical dimension and hablumminannas or horizontal dimension.

There is very noticeable difference between the zakat potential and its receipt realization by Zakat Management Organization (ZMO). Allegedly the problem occurs because it is lack of public trust to $\mathrm{ZMO}$, as the opinion of Jamil [1] that the zakat fund managers are still considered not to have human resources (amil zakat) whose quality is optimal.

Public trust is closely related to the quality of the financial information which is presented by ZMO. The information will be useful if the information is able to support the community decision-making to entrust their zakat to ZMO as an institution which is considered mandate to receive, utilize and distribute zakat which is entrusted by community.

The fundamental difference between Islamic financial institutions (IFIs) and conventional is in the existence of supervision over the implementation of Islamic law. Sharia Supervision is a process to ensure that financial products and services according to the principles of Islam. SSB is a very important organ in the IFIS, SSB ensures all the objectives of Islamic governance are achieved, which includes directing, reviewing and supervising all the activities of IFIs in order to adhere to sharia. Karim [2] argues that SSB is also involved in accounting policies and sharia reporting, it can be justified that the report could convince the reader that the financial statements are based on Islamic law. Quality financial statement is suitable with generally accepted accounting principles and meets the existing rules and SSB ensures the credibility of financial statements [3].

\section{CONCEPTUAL FRAMEWORK}

The financial statement is the financial effects overview of transactions and other events which are classified into several large groups according to their economic characteristics. The large group is the elements of financial statements. The elements that are directly related to the measurement of financial position are assets, liabilities, and equity. Meanwhile, the elements that are related to performance measurement in the income statement are income and expenses. The statement of changes in financial position usually reflects income statement elements and changes in balance sheet elements; thus, the basic framework is not identified particularly the elements of the changes statement in financial position.

In contrast to the financial statements which are the output of accounting, financial reporting is not the final product it is a process that starts from the transactions/events, the selection of accounting policies and then apply the policy. Financial reporting also involves estimates and judgments as well as the disclosures about transactions, events, policies, estimates and judgments that have been made. The quality of financial reporting depends on the quality of each part of the financial reporting process [4].

The definition of SSB according to the Accounting and Auditing Organization for Islamic Financial Institution [5] is:

A Sharia supervisory board (SSB) is an independent body of (Sharia scholars) with a (possibility of including) a member other than a sharia scholar, who should be an expert in the field of Islamic Financial Institutions (IFIs). The SSB is entrusted with the duty of directing, reviewing, and supervising the activities of the IFIs in order to ensure that they are in compliance with Islamic Sharia. 
Rahman in his book The Art of Islamic Banking and Finance [6] states that:

The Sharia Board (sometimes called Sharia Supervisory Committee), in general, certifies every product, finance model, and service provided by the Risk Free financial institution. It also ensures that all the transactions are in strict compliance with the principles of Sharia

Rosly [7] states that there is the sharia supervisory board role in ensuring the implementation of sharia maqasid and inspecting the implementation of transaction agreement in sharia banks, which also affects financial reporting.

The SSB independence is very important for financial statements users who require collateral for Islamic transactions and operations of sharia bank. The SSB independence and the external auditor affect the credibility of financial statements [2].

In giving advice, SSB must guarantee all the bank's operations are based on the sharia rules. Karim [2]. The SSB independence is strongly influenced by moral values, while the external auditors are largely influenced by economic factors. SSB and independent external auditors are to ensure the credibility of financial statements.

\section{RESEARCH METHODS}

The method which is used in this study is a survey method, because it has the characteristics that are associated with the objectives to be achieved, it is descriptive and verification, and the data is collected from a sample that has been determined, it is obtained by using a specific data collection tools, the questionnaires [8].

The object of this research are the role of sharia supervisory board, and the quality of financial reporting. The research subject is ZMO which operates in Bandung city. The respondents in this study are director, members of sharia supervisory board as well as Zakat collection and utilization. The data which is obtained from the ZMO respondents will be averaged, so that the opinion of respondents representing each ZMO. The data source which is required in this research will be obtained through the Field Research by distributing questionnaires and Research Library (Library Research). The data quality which is obtained from the respondents through the questionnaire needs to be tested by doing validity test and reliability test to avoid things that are biased and question the validity of this study.

The testing hypothesis uses moment product correlation and coefficient of determination (R2). The coefficient of determination measures how far the ability of the model in explaining variations on dependent variable [9]. The more the value of $\mathrm{R} 2$ is closed to one then the independent variable provides almost all the information which is needed to predict the variation of dependent variable. On the contrary, if the value of R2 is getting smaller, the ability of independent variable in explaining the dependent variation is very limited.

\section{RESULT}

Based on the results of hypothesis testing, the study found that the relation of sharia supervisory board role with the quality of financial reporting is positive and very strong. Public trust is closely associated with the financial information quality which is presented by ZMO. The information will be useful if the information is able to support the community decision-making to entrust their zakat to ZMO as an institution that is considered a mandate to receive, utilize and distribute zakat which is entrusted by community. On the other hand, muzakki requires transparency and accountability for the use of zakat funds. SSB has the competence to ensure ZMO accordance with sharia. SSB role has related very strong and positive to the quality of financial reporting. Financial statements are credible information sources by the financial statements users to determine the performance of management and the company's financial position. Therefore, the role of the SSB can improve the quality of financial reporting that will ultimately result in increased public confidence in the ZMO.

Casper [10] divides SSB functions into three, namely certification, supervision and guidance functions. Garas and Pierce [11] find that SSB function is convincing IFIs activities based on sharia by way of overseeing the management and conducting IFIs training.

In carrying out its functions SSB should have religious competence, legal, social, corporate governance, economic [11]. IFIS should have SSB who has sufficient financial knowledge in addition to knowledge in sharia, so SSB can assist management in developing products which appropriates to sharia [12]. IFIs is managed differently because it is based on principles and rules of Islam, and the principles must be implemented and able to be reflected in the behaviour based on the faith that is integrated with the knowledge [13].

Financial crimes can be more prevented in IFIs because there are laws of Quran and hadits which are the basis of rules and principles [14]. And the presence of SSB in IFIs affects the company addedvalue and increases the competitive advantage [15].

Chapra and Ahmed [16] also say that the importance of sharia supervisory board role. Rosly [7] states that there is sharia supervisory board role in ensuring the implementation of maqasid sharia and examining the implementation of agreement in transaction, which also affects financial reporting. SSB and the independence of the external auditor affect the credibility of financial statements [3]

\section{CONCLUSION}

Based on the results of statistical calculations, it is concluded that the relation of sharia supervisory board role with the quality of financial reporting is positive and very strong. Financial statements are credible information sources by the financial statements users to determine the performance of management and the company's financial position. Therefore, the role of the SSB can improve the quality of financial reporting that will ultimately result in increased public confidence in the ZMO. 


\section{REFERENCES}

[1] Jamil Azzaini.2008. Berdayakan Lembaga Amil Zakat. Republika. Jumat, 19 September 2008: 9

[2] Karim,R,A,A,. 1990. Standar setting for the financial reporting of the religious business organization: the case of islamic banks. Accounting and business research, vol 20, No. 80, 299 - 305.

[3] Karim,R,A,A,. 1990. Independence of religious and external auditors : the case of islamic banks. Auditing, accounting and accountibility journal, vol 3, No.3, $33-44$.

[4] Jonas, Gregory and Jeanot, Blanchet.2000. Asessing Quality of Internal Quality.Accounting Horizon, Sept; 14,3 , 353

[5] AAOIFI. 2008. Accounting and Auditing Organization for Islamic Financial Institutions. Manama,Bahrain:AAOIFI

[6] Rahman,Yahia,Abdul. 2010. The art of islamic banking and finance. United States: John Wiley\&Sons

[7] Rosly, Saiful Azhar. 2010. Shariah parameters considered. International Journal of Islamic and Middle Eastern Finance and Management. Vol. 3 No. 2, 132 - 146

[8] Singarimbun,Masri and Sofyan Effendi. 2005. Metode Penelitian Survey. Jakarta: LPE3S

[9] Imam, Ghazali. 2006. Aplikasi Analisis Multivariate dengan Program SPSS. Semarang: Badan Penerbit Universitas Diponegoro

[10] Casper, Mathias. 2012. Sharia boards and sharia compliance in the eropean corporate governance. http://ssrn.com/abstract=2179412

[11] Garas, Samy,Natan and Pierce Chris . 2010. Sharia Supervision of islamic financial institution. Journal of Financial Regulation and Compliance Vol. 18 No. 4, 2010 pp. 386-407

[12] Ghayad, Racha. 2008. Corporate Governance and the global performance of islamic bank. Humanomics Vol 24 No 3, 207 -216

[13] Choudhury ,Masudul Alam dan Haque , M. Ziahoul . 2006. Corporate Governance in islamic perspective. Vol 6 No 2. www.emeraldinsight.com

[14] Jabbar,Siti Faridah Abdul.2010. Financial crimes:

Prohibition in Islam and prevention by the sharia'a supervisoy board in islamic financial institution. Journal of Financial Crime Vol. 17 No. 3, 287-294

[15] Nathan, Sami dan Riebielle, vincene . 2007. From knowledge to wisdom: the case of corporate governance in islamic banking. The Jorunal of Knowledge and Managment System, Vol 37 No. 4 . 471-483

[16] Chapra,U.M, and Ahmed, H. 2002. Corporate Governance in Islamic Financial Institution. Occasional Paper No. 6 Jeddah Islamic Research and Training Institute. Islamic development Bank. 